\title{
PEMBELAJARAN MATEMATIKA YANG MENGACU MULTIPLE INTELIGENCES PADA MATERI STATISTIK DI KELAS XI IPS SMA NEGERI 2 BATU
}

\author{
DEDY SETYAWAN \\ Dosen Pada Fakultas Keguruan dan IImu Pendidikan \\ Universitas Muhammadiyah Palangkaraya
}

\begin{abstract}
The number of national examination become decrease, one of the subjects is mathematic. Thus, it needs to apply a learning based on student intelligences. It can be applied in mathematic base on student personal intelligence.

The research used learning with multiple intelligences in mathematic subject. It was applied at Statistic lesson to eleventh grade students of SMAN 02 BATU. The aim of the research is to find out how were the activities and the result of study.

The research design used in this study was a descriptive qualitative research. The subject of research was the students of XI IPS class on SMAN 02 BATU. The variable of this research were student's activities and students score. The instruments used of this study were questionnaire and students score. Data analysis used of this study was percentage analyzing to measure the activities and students score.

The result of the research showed that the number of students activities was quite enough with 68, $63 \%$. The result of completeness analyzing student learning after using multiple intelligence with 28 students was complete and one of them was failed. The completeness of personal classical study with SKBM was 96, $55 \%$.
\end{abstract}

Keywords : multiple intelligence, students activities, result of study

\begin{abstract}
ABSTRAK
Tingkat kelulusan ujian nasional tiap tahun semakin menurun, salah satunya pada pelajaran matematika. Sehingga perlu diterapkan pembelajaran yang sesuai dengan kecerdasan siswa. pada pelajaran matematika dapat di terapkan pembelajaran Multiple Intelligence yang sesuai dengan kecerdasan yang dimiliki setiap individu.

Penelitian Pembelajaran Multiple Intelligences dalam pembelajaran matematika pada materi statistika di Kelas XI IPS SMA Negeri 2 Batu. Tujuan dari penelitian ini adalah untuk mengetahui bagaimana aktivitas dan hasil belajar siswa.

Penelitian yang dilakukan merupakan penelitian deskriptif kualitatif. Adapun subyek dalam penelitian ini adalah siswa kelas XI IPS SMA Negeri 2 Batu. Variabel dalam penelitian ini adalah aktivitas dan hasil belajar siswa. Instrumen yang digunakan adalah lembar observasi dan tes hasil belajar. Analisa data yang digunakan penelitian ini adalah analisa persentase untuk mengukur aktivitas dan hasil belajar siswa.

Hasil penelitian menunjukkan bahwa tingkat aktivitas siswa adalah cukup dengan persentase $68,63 \%$. Sedangkan hasil analisis ketuntasan belajar siswa setelah penerapan pembelajaran Multiple Intelligence dalam matematika terdapat 28 siswa yang dikatakan tuntas dan 1 siswa tidak tuntas. Ketuntasan individu belajar klasikal di atas SKBM yaitu sebesar $96,55 \%$.
\end{abstract}

Kata Kunci : multiple intelligence, aktivitas siswa, hasil belajar siswa 


\section{PENDAHULUAN}

Tingkat kelulusan Ujian Nasional (UN) siswa SMA dan MA tahun 2010 secara nasional mengalami penurunan sebesar $4 \%$ bila dibanding tahun 2009 lalu, yakni dari 93,74\% menjadi 89,88\%. "Angka kelulusan ujian nasional (UN) tingkat SMA/MA tahun 2010 memang mengalami penurunan bila dibandingkan tahun 2009." (http://www.klipberita.com) Khusus untuk data Kota Malang, jumlah siswa tidak lulus untuk SMA masih berupa prakiraan yang mencapai 500 orang. Hasil berbeda terjadi di Kabupaten Malang dan Kota Batu. Di kabupaten angka kelulusan naik dibandingkan tahun sebelumnya. Sementara di Kota Batu, justru jeblok. Bahkan Kota Batu berada di peringkat paling bawah di Jawa Timur.SMAN 2 Batu, dari 302 siswa yang mengikuti ujian nasional, terdapat 45 siswa yang tak lulus ujian. Siswa yang tak lulus umumnya karena nilai matematikanya anjlok. Padahal nilai mata pelajaran lain untuk jurusan IPA terbilang tinggi. Hal tidak lepas dari sulitnya mencapai nilai kelulusan mata pelajaran. Matematika adalah pelajaran yang menjadi kendala terbesar bagi siswa-siswi untuk lulus dalam ujian nasional.

Akan tetapi pemerintah memberikan ujian nasional tahap dua bagi peserta ujian nasional yang tidak lulus pada tahap satu. Ujian nasional tahap dua batu terdiri dari 431 siswa, akan tetapi terdapat 54 siswa yang tidak lulus pada ujian nasional tahap dua ini. Kendala utama yang dihadapi adalah siswa tidak mampu melewati standar kelulusan matematika yaitu 5,5.(Mahrani, lia; Radar Malang, 5 Juni 2010)

Dari tahun ke tahun, matematika banyak menjadi momok yang menakutkan bagi semua orang. Hal ini tidak lepas dari pelajaran matematika yang merupakan pelajaran berhitung. Sehingga bagi kalangan siswa khususnya mereka menjadi menjauhi pelajaran matematika. Hanya sebagian kecil dari siswa yang menyukai pelajaran matematika tersebut. dalam situasi pembelajaran yang berlangsung secara monoton, siswa merasa "tersiksa" dan bahkan seperti dipenjara, apalagi guru sebagai motivator dalam pembelajaran yang biasanya hanya menggunakan metode ceramah di depan kelas membuat pembelajaran semakin tidak menyenangkan.

Salah satu faktor pendukung dalam pembelajaran adalah metode pengajaran. Guruguru terkadang sering memberikan materi kapada muridnya secara monoton dan terus menerus tanpa ada variasi yang digunakan. Hal ini membuat siswa menjadi bosan dan tidak dapat menerima pelajaran dengan baik. Sehingga dibutuhkan metode pengajaran yang tepat, supaya nantinya siswa bisa menerima materi yang disampaikan dengan baik.

Setiap individu dapat memiliki satu atau lebih kecerdasan, sehingga membutuhkan metode belajar dan pemahaman yang beragam. Sehingga penting bagi setiap pendidik untuk memahami esensi dari kecerdasan jamak ini untuk perkembangan anak dan kemajuan akademisnya, karena setiap anak memiliki potensi dan kapasitas yang berbeda-beda. Pandangan ini perlu dicermati, sehingga pendidik dapat membantu murid-muridnya untuk mencapai yang terbaik.

Selama ini, tidak sedikit kita jumpai hasilhasil penelitian, buku, jurnal atau lainnya yang menawarkan pelbagai konsep strategi dan model pembelajaran matematika yang efektif untuk 
diterapkan pada proses pembelajaran. Selain itu, juga seringkali dilakukan perombakan kurikulum matematika yang bertujuan untuk menyesuaikan dengan perkembangan siswa. Namun, ikhtiar tersebut ternyata belum sepenuhnya menampakkan hasil maksimal sebagaimana yang diinginkan oleh banyak pihak. Karena, dalam praktiknya, tawaran yang diberikan belum mampu mengembangkan kecerdasan matematis siswa secara maksimal dan mendesain gaya belajar sesuai dengan kecerdasan masing-masing siswa. Hal ini disebabkan model pembelajaran yang ditawarkan dan kurikulum yang didesain tidak dibangun berdasarkan keragaman gaya belajar dan potensi kecerdasan yang dimiliki setiap individu pebelajar.

Pada materi statistika banyak sekali metode yang dapat di gunakan dalam pembelajaran, salah satunya adalah Multiple Intelligences. Karena nantinya siswa dapat dituntut untuk memiliki berbagai kecerdasan, seperti halnya kecerdasan menggembar diagram, mencari data pada kehidupan sehari-hari dan masih banyak lagi lainnya.

Teori Multiple intelligence bertujuan untuk mentransformasikan sekolah agar kelak sekolah dapat mengakomodasi setiap siswa dengan berbagai macam pola pikirnya yang unik.

Kita bisa mencontohkan apakah Einstein akan sukses seperti itu bila dia masuk di Jurusan Biologi atau belajar main bola dan Musik, jelas masalah fisika-teoritis Einstein, Max Planc, Stephen Howking, Newton adalah jenius-jenius, tetapi bab olah-raga maka Zidane, Jordane, Maradona adalah jenius-jenius dilapangan, juga Mozart, Bach adalah jenius-jenius dimusik. Dan seterusnya juga Thoman A. Edison adalah jenius lain, demikian juga dengan para sutradara film, bagaimana mereka mampu membayangkan harus disyuting bagian ini, kemudian setelah itu, adegan ini, ini yang mesti keluar dengan pakaian jenis ini, latar suara ini, dan bahkan dialog seperti itu, ini adalah jenius-jenius bentuk lain. Disinilah Howard Gardner mengeluarkan teori baru dalam buku Frame of Mind, tentang Multiple Intelligences (Kecerdasan Majemuk), dimana dia mengatakan bahwa era baru sudah merubah dari Test IQ yang melulu hanya test tulis (dimana didominasi oleh kemampuan Matematika dan Bahasa), menjadi Multiple Intelligences.

Melalui teori kecerdasan ganda (Multiple Intelligence) ini yang ditemukan oleh pakar Psikologi Harvard Howard Gardner bahwa seseorang memiliki lebih dari satu kecerdasan. Howard Gardner menyatakan ada delapan kecerdasan yang dimiliki oleh setiap individu (Gardener Howard, 1982). Teori teori tersebut antara lain adalah Linguistic Inteligence(kecerdasan linguistik), LogicalMathematical Intelligences (Kecerdasan logika matematika), Visual-spatial intelligences (kecerdasan visual-spasial), Bodily-Kinesthetic Intelligences (kecerdasan kinestik-tubuh), Musical Intelligences (Kecedasan musical), Interpersonal Intelligences (Kecerdasan Interpersonal), Intrapersonal Intelligences (Kecerdasan Intrapersonal), naturalist Intelligences (Kecerdasan naturalis).

Teori ini menuntut siswa untuk mengembangkan kecerdasan yang dimilikinya. Setiap siswa berbeda-beda tingkat kecerdasan yang dimilikinya. Karena tidak semua siswa memiliki bisa memiliki delapan kecerdasan yang menonjol. Terkadang hanya beberapa 
kecerdasan saja yang menonjol pada setiap siswa. Terkadang seseorang yang idiot memiliki salah satu kecerdasan yang menonjol. Misalnya dia mehir bermain gitar, melukis dll.

\section{METODE PENELITIAN}

Pendekatan yang digunakan dalam penelitian ini adalah pendekatan kualitatif, hal ini dikarenakan data yang diperoleh dinyatakan dalam bentuk verbal dan dianalisis tanpa analitik statistika. Pendekatan ini melihat situasi nyata yang berubah secara alamiah dan tidak ada rekayasa pengontrolan variablel. Sedangkan jenis penelitian yang dilakukan adalah penelitian deskriptif. Penelitian ini dirancang untuk mendeskripsikan atau menggambarkan fenomena-fenomena yang ada. Penelitian deskriptif diarahkan untuk memberikan gejalagejala, fakta-fakta atau kejadian-kejadian secara sistematis dan akurat, mengenai sifat-sifat populasi atau daerah tertentu (Moleong, J. Lexy, 1994) Penelitian ini berusaha untuk mendeskripsikan akibat yang terjadi selama dan setelah pembelajaran dilakukan.

Subjek dalam penelitian ini adalah siswa kelas XI Jurusan IPS di SMA Negeri 2 Batu. Dengan mengambil sampel 6 orang siswa secara acak. Pemilihan kelas penelitian ini berdasarkan hasil wawancara dengan guru matematika kelas XI Jurusan IPS di SMA Negeri 2 Batu. Hasil kegiatan yang berkaitan secara langsung dalam pelaksanaan penelitian merupakan data yang dikumpulkan. Adapun data yang diambil dalam penelitian ini adalah: (1) Hasil Analisis terhadap observasi aktivitas siswa. (2) Hasil tes belajar yang digunakan untuk melihat ketuntasan hasil belajar siswa.

\section{PEMBAHASAN}

Pertemuan Pertama

Pada pertemuan pertama ini, terlebih dahulu dijelaskan tentang materi bagaimana menyajikan data dalam bentuk tabel dan diagram batang, garis, dan lingkaran. Peneliti mengambil contoh data dari lingkungan sekitar kelas seperti halnya tinggi badan dalam kelas. Hal ini di lakukan agar siswa dapat lebih mudah memahami materi penyajian data ini. Setelah materi di berikan, maka setiap siswa diberikan LKS1.

LKS 1 ini berupa soal-soal menyajikan data dalam bentuk tabel dan diagram batang, garis, dan lingkaran. Soal-soal tersebut di maksudkan untuk menggali kecerdasan Visual spatial Intelligence pada setiap siswa, sehingga kemampuan Visual spatial Intelligence setiap individu dapat di berkembang.

Setelah selesai mengerjakan LKS 1, setiap siswa di arahkan untuk menukar jawaban mereka dengan teman sebangku mereka masingmasing. Kemudian diminta beberapa siswa mengerjakan di papan tulis, agar dapat dilihat oleh siswa yang lain yang sedang memeriksa hasil pekerjaan temannya. Peneliti di sini membantu mengarahkan siswa bila ada yang salah dalam mengerjakan LKS 1 di papan tulis. Kemudian siswa di arahkan untuk memberi nilai pada hasil pengerjaan temannya masing-masing. Sehingga siswa belajar melihat dan mengamati, mengenali bentuk-bentuk diagram. Hal ini di lakukan agar setiap siswa mampu menggali kemampuan Visual spatial Intelligence mereka masing-masing dengan mengetahui bagaimana jawaban yang benar dan salah.

Kemudian dalam penelitian ini dilakukan tinjauan ulang terhadap jawaban yang dibuat oleh 
siswa, serta kekuatan dan kelemahan dalam proses pengerjaan siswa. Selanjutnya siswa membuat ringkasan dan menemukan ide-ide pokok materi yang dipelajari tadi, kemudian penelitian hari ini diakhiri dengan salam dan sebelum mengakhiri pembelajaran peneliti meminta siswa belajar lagi di rumah karena pertemuan selanjutnya akan diadakan tes.

Pertemuan Kedua

Sebelum ujian di mulai, peneliti membagikan lembar LKS 2 kepada setiap siswa untuk menggali kembali potensi Visual spatial Intelligence mereka. Hal ini dilakukan agar siswa mengingat kembali materi sebelunya yang telah di ajarkan.

LKS 2 ini berupa soal-soal menyajikan data dalam bentuk tabel dan diagram batang, garis, dan lingkaran. Soal-soal tersebut di maksudkan untuk menggali kecerdasan Visual spatial Intelligence pada setiap siswa, sehingga kemampuan Visual spatial Intelligence setiap individu dapat di berkembang dan juga membuat siswa mengingat kembali pada materi yang lalu.

Dalam pelaksanaan pengerjaan LKS 2 , peneliti berkeliling untuk membantu mengarahkan siswa dalam mengerjakan LKS 2, sehingga bagi siswa-siswa dengan kemampuan Visual spatial Intelligence yang masih kurang, dapat terbantu dengan pengarahan yang diberikan.

Setelah selesai mengerjakan LKS 2, setiap siswa di arahkan untuk menukar jawaban mereka dengan teman sebangku mereka masingmasing. Kemudian diminta beberapa siswa mengerjakan di papan tulis, agar dapat dilihat oleh siswa yang lain yang sedang memeriksa hasil pekerjaan temannya. Peneliti di sini membantu mengarahkan siswa apabila ada yang salah dalam mengerjakan LKS 2 di papan tulis. Kemudian siswa di arahkan untuk memberi nilai pada hasil pengerjaan temannya masing-masing. Sehingga siswa belajar melihat dan mengamati, mengenali bentuk-bentuk diagram $\mathrm{Hal}$ ini di lakukan agar setiap siswa mampu menggali kemampuan Visual spatial Intelligence mereka masing-masing dengan mengetahui bagaimana jawaban yang benar dan salah.

Kemudian dilanjutkan dengan membagikan lembar soal tes 1 dan lembar jawaban kepada setiap siswa dan menginformasikan peraturan-peraturan dalam mengerjakan tes. Siswa mengerjakan tes secara individu dan berakhir sesuai dengan waktu yang ditentukan, yaitu 40 menit, sedangkan guru mengawasi jalannya tes. Setelah berakhirnya waktu untuk mengerjakan tes, siswa mengumpulkan lembar jawaban dan peneliti mengakhiri pembelajaran dengan salam.

Pertemuan Ketiga

Pada pertemuan ketiga ini, terlebih dahulu diberikan penjelasan tentang materi bagaimana menghitung ukuran pemusatan, ukuran letak, dan ukuran penyebaran data, serta menafsirkannya. Peneliti mengambil contoh data dari lingkungan sekitar kelas seperti halnya berat badan dalam kelas. Hal ini di lakukan agar siswa dapat lebih mudah memahami materi penyajian data ini. Setelah materi di berikan, maka setiap siswa diberikan LKS 3.

LKS 3 ini berupa soal-soal menghitung mean, modus serta median. Soal-soal tersebut di maksudkan untuk menggali kecerdasan Logical Mathematical intelligence pada setiap siswa, sehingga kemampuan Logical Mathematical intelligence setiap individu dapat di berkembang. 
Dalam pelaksanaan pengerjaan LKS 3 , peneliti berkeliling untuk membantu siswa yang masih bingung dengan materi, sehingga bagi siswa-siswa dengan kemampuan Logical Mathematical intelligence yang masih kurang, dapat terbantu dan digali kembali pada diri mereka masing-masing, dengan pengarahanpengarahan yang sifatnya mengarahkan siswa pada jalan keluaratau hasil dari LKS 3 tersebut.

Setelah selesai mengerjakan LKS 3, setiap siswa di arahkan untuk menukar jawaban mereka dengan teman sebangku mereka masingmasing. Kemudian Peneliti meminta beberapa siswa mengerjakan di papan tulis, agar dapat dilihat oleh siswa yang lain yang sedang memeriksa hasil pekerjaan temannya. Peneliti di sini membantu mengarahkan siswa bila ada yang salah dalam mengerjakan LKS 3 di papan tulis. Kemudian siswa di arahkan untuk memberi nilai pada hasil pengerjaan temannya masing-masing. Hal ini di lakukan agar setiap siswa mampu menggali kemampuan Logical Mathematical intelligence mereka masing-masing dengan mengetahui bagaimana jawaban yang benar dan salah.

Kemudian pada penelitian ini dilakukan tinjauan ulang terhadap jawaban yang dibuat oleh siswa, serta kekuatan dan kelemahan dalam proses pengerjaan siswa. Selanjutnya siswa membuat ringkasan dan menemukan ide-ide pokok materi yang dipelajari tadi, kemudian diakhiri dengan salam

\section{Pertemuan Keempat}

Sebelum ujian di mulai, peneliti membagikan lembar LKS 4 kepada setiap siswa. LKS 4 ini berupa soal-soal menghitung mean, modus serta median. Soal-soal tersebut di maksudkan untuk menggali kecerdasan Logical Mathematical intelligence pada setiap siswa, sehingga kemampuan Logical Mathematical intelligence setiap individu dapat di berkembang.

Dalam pelaksanaan pengerjaan LKS 4, peneliti berkeliling untuk membantu mengarahkan siswa dalam mengerjakan LKS 4 , sehingga bagi siswa-siswa dengan kemampuan Logical Mathematical intelligence yang masih kurang, dapat terbantu dengan pengarahan dari peneliti.

Setelah selesai mengerjakan LKS 4, setiap siswa di arahkan untuk menukar jawaban mereka dengan teman sebangku mereka masingmasing. Kemudian peneliti meminta beberapa siswa mengerjakan di papan tulis, agar dapat dilihat oleh siswa yang lain yang sedang memeriksa hasil pekerjaan temannya. Peran peneliti di sini membantu mengarahkan siswa apabila ada yang salah dalam mengerjakan LKS 4 di papan tulis. Kemudian siswa di arahkan untuk memberi nilai pada hasil pengerjaan temannya masing-masing. Hal ini di lakukan agar setiap siswa mampu menggali kemampuan Logical Mathematical intelligence mereka masing-masing dengan mengetahui bagaimana jawaban yang benar dan salah.

$$
\text { Kemudian dilanjutkan dengan }
$$
membagikan lembar soal tes 2 dan lembar jawaban kepada setiap siswa dan menginformasikan peraturan-peraturan dalam mengerjakan tes. Siswa mengerjakan tes secara individu dan berakhir sesuai dengan waktu yang ditentukan, yaitu 40 menit, sedangkan guru mengawasi jalannya tes. Setelah berakhirnya waktu untuk mengerjakan tes, siswa mengumpulkan lembar jawaban dan penelitian diakhiri dengan salam. 
Jumlah siswa yang terdapat di kelas XI IPS 1 SMA Negeri 2 Batu adalah 29 siswa. Dipilih secara acak 6 siswa yang akan diamati selama pembelajaran berlangsung. Observer yang dipakai adalah 2 orang, masing-masing observer mengamati 3 orang siswa. Dari hasil observasi aktivitas siswa diperoleh data sebagai berikut:

Dari aktivitas siswa dengan kategori relevan diperoleh data dari penelitian sesuai dengan tabel 1 dari tabel tersebut diperoleh ratarata aktivitas untuk kategori relevan adalah 68,65 $\%$ dan dikategorikan cukup. Hal tersebut dikarenakan siswa sangat antusias dalam (a) mendengarkan/memperhatikan penjelasan guru atau teman dengan aktif, (b) siswa membaca/memahami serangkaian penjelasan dan pertanyaan Visual Spatial Intelligence \& Logical mathematical Intelligenceyang tertera di LKS, (c) menyelesaikan masalah/mengerjakan LKS, (d) menyampaikan pendapat/ide kepada guru dan/atau teman, (e) berdiskusi/bertanya kepada teman dan/atau guru, (f) mendemontrasikan hasil diskusi dan (g) menarik kesimpulan suatu prosedur atau konsep (siswa membuat rangkuman).

Dari Data pada tabel 2 tersebut maka untuk ketuntasan belajar klasikal sebesar $96,55 \%$, sehingga dapat disimpulkan bahwa ketuntasan belajar klasikalnya sudah mencapai SKBM, yaitu di atas $70 \%$.

Tabel 1. Aktivitas Siswa yang relevan

\begin{tabular}{|c|c|c|c|c|}
\hline \multirow[b]{2}{*}{$\begin{array}{l}\text { Nama } \\
\text { Siswa }\end{array}$} & \multicolumn{3}{|c|}{ Jumlah Aktivitas } & Hasil \\
\hline & $\begin{array}{l}\text { Pertemuan } \\
\text { Pertama }\end{array}$ & $\begin{array}{l}\text { Pertemuan } \\
\text { Ketiga }\end{array}$ & Total & $\begin{array}{c}\text { Persentase } \\
(\%)\end{array}$ \\
\hline 1 & 53 & 57 & 110 & 65,47 \\
\hline 2 & 55 & 55 & 110 & 65,47 \\
\hline 3 & 58 & 58 & 116 & 69,04 \\
\hline 4 & 56 & 57 & 113 & 67,26 \\
\hline 5 & 63 & 60 & 123 & 73,21 \\
\hline 6 & 60 & 60 & 120 & 71,43 \\
\hline Rata-rata & 57,5 & 57,8 & 57,6 & 68,65 \\
\hline
\end{tabular}

Tabel 2.Persentase Tingkat hasil Belajar Siswa dalam Satu Kelas

\begin{tabular}{|c|c|c|c|}
\hline Nilai & Jumlah (siswa) & Persentase (\%) & Keterangan \\
\hline$\geq 65$ & 28 & $96,55 \%$ & Tuntas \\
\hline$<65$ & 1 & $3,45 \%$ & Tidak tuntas \\
\hline
\end{tabular}




\section{KESIMPULAN}

Dari pembahasan yang telah diuraikan pada bab sebelumnya, maka dapat ditarik kesimpulan sebagai berikut:

a. Aktivitas siswa selama penerapan model pembelajaran Multiple Intelligence Dalam Pembelajaran Matematika Pada Materi Statistika di Kelas XI IPS SMA Negeri 2 Batu adalah siswa melakukan aktivitas relevan dan tidak relevan. Aktivitas relevan yaitu (1) siswa mendengarkan/memperhatikan penjelasan guru atau teman dengan aktif; (2) siswa membaca/memahami serangkaian penjelasan dan pertanyaan yang tertera di LKS; (3) siswa menyelesaikan masalah/mengerjakan LKS; (4) siswa menyampaikan pendapat/ide kepada guru dan/atau teman; (5) siswa berdiskusi/bertanya kepada teman dan/atau guru; (6) siswa mendemontrasikan hasil diskusi; (7) siswa menarik kesimpulan suatu prosedur atau konsep (siswa membuat rangkuman), dapat dikatakan cukup dengan persentase $68,65 \%$

b. Hasil analisis ketuntasan belajar siswa setelah penerapan Multiple Intelligence dalam pembelajaran matematika pada materi statistika di Kelas XI IPS SMA Negeri 2 Batu dari 29 siswa terdapat 28 siswa yang dikatakan tuntas dan 1 siswa tidak tuntas. Ketuntasan individu belajar klasikal sudah di atas SKBM yaitu sebesar $96,55 \%$.

\section{DAFTAR PUSTAKA}

Jurnal, Anterior. 2009. Volume 9 Nomor 1. Palangka Raya. Lembaga Penelitian dan Pengabdian Kepada Masyarakat Universitas Muhammadiyah palangkaraya.

Gardner, Howard. 1982. Seni, Pikiran dan Otak. New York : Basic Books

Indonesia, Media. 2010. Tingkat kelulusan ujian nasional SMA turun 4\%. (Online) (http://www.klipberita.com/klipnews/8392-tingkat-kelulusan-ujiannasional-sma-turun-4-persen.html)

Maharani, lia. 2010. Ujian nasional tahap dua bagi peserta ujian nasional. Malang: Radar malang.

Moleong, J Lexy. 1994. Metode Penelitian Kualitatif. Bandung: PT Remaja Rosda Karya. 